\title{
Strategic Information Systems Enabling Strategy-as-Practice and Corporate Performance: Empirical Evidence from PLS-PM, FIMIX-PLS and fsQCA
}

\author{
Adilson Carlos Yoshikuni ${ }^{1}$, Edimilson Costa Lucas $^{2}$, Alberto Luiz Albertin ${ }^{3}$ \\ ${ }^{1}$ Professor and researcher, School of Business Administration of São Paulo of Fundação Getulio Vargas \\ (FGV-EAESP), Brazil. E-mail: acyoshikuni@hotmail.com \\ ${ }^{2}$ Professor, Federal University of Sao Paulo (EPPEN-UNIFESP), Brazil. E-mail: prof.eclucas@gmail.com \\ ${ }^{3}$ Full Time Professor, School of Business Administration of São Paulo of Fundação Getulio Vargas \\ (FGV-EAESP), Brazil. E-mail: albertin@fgv.br \\ Correspondence: Adilson Carlos Yoshikuni, Av. 9 de Julho, 2029, Bela Vista, 01313-902, São Paulo, Brazil.
}

Received: November 20, 2018

doi:10.5539/ibr.v12n1p131
Accepted: December 24, 2018 Online Published: December 27, 2018

URL: https://doi.org/10.5539/ibr.v12n1p131

\begin{abstract}
Many studies have been investigating how IS (information systems) can help build a corporate performance, but there are less research investigating how IS contributing to performance by mediating business strategy in uncertain environments. To address this question, the present study seeks to empirically explore the relationship between strategic information systems and corporate performance by mediating business strategy. Partial Least Squares-Path Modeling (PLS-PM) confirmed SIS's strong influence on strategy, and full strategy mediation on the relationship between SIS and performance. SIS showed greater performance contribution in high heterogeneity environments than in lower ones, and small and medium-sized firms have 50\% more contribution of the effects of strategy on performance than large firms. The post-hoc-analysis study did not identify the presence of heterogeneity segmentation not observed by Finite Mixture (FIMIX-PLS). Through fuzzy set qualitative comparative analysis (fsQCA), non-linear causality was verified in the strategy in certain solutions by the variables of large firms, with intensive use of SIS and high environmental heterogeneity. Moreover, the study demonstrated that SIS's strategic alignment has strong effects and explanation power on performance and may suggest that it is an indissociable resource for the strategy-as-practice effectiveness. Hence, the study contributed to understanding how SIS create value to strategy-as-practice approach under environmental turbulence to impact corporate performance.
\end{abstract}

Keywords: strategic information systems, strategy-as-practice, business strategy, IS strategy, FIMIX-PLS and fsQCA approach

\section{Introduction}

Over the years environmental turbulence has challenged organizations to develop business strategies that impact on corporate performance (Whittington, Yakis-Douglas, Ahn, \& Cailluet, 2017). Since 1990s, increasing environmental turbulence has generated radical implications for strategy management practices (Wolf \& Floyd, 2017; Yoshikuni \& Albertin, 2018a). Hence, the strategy evolves to the strategy-as-practice approach, which through IT/IS enables organizations to address the challenges of environmental uncertainty (Jarzabkowski \& Kaplan, 2015; Whittington et al., 2017).

The contemporary strategies approaches are essential means for organizations to compete, obtain better corporate performance (CP) in highly complex and dynamic environments (Babafemi, 2015; Hill, Jones, \& Schilling, 2014; Miller \& Friesen, 1983; Mintzberg, Ahlstrand, \& Lampel, 2009; Porter, 1986; Skokan, Pawliczek, \& Piszczur, 2013; Whittington et al., 2017), and in the latter have intensified the research of IS strategy contribution (D. Q. Chen, Mocker, Preston, \& Teubner, 2010; Leidner, Lo, \& Preston, 2011) incorporated into the routines of BS (Arvidsson, Holmström, \& Lyytinen, 2014; Newkirk \& Lederer, 2006; Yoshikuni \& Albertin, 2018b), enabling it as strategy-as-practice (Marabelli \& Galliers, 2017; Peppard, Galliers, \& Thorogood, 2014; Whittington, 2014; Yoshikuni \& Albertin, 2018a) on the effects of turbulence and environmental uncertainty (Y. Chen et al., 2014; Merali, Papadopoulos, \& Nadkarni, 2012; Mikalef \& Pateli, 2017; Newkirk \& Lederer, 2009; Teo \& King, 1997). 
This study was carried out with firms located in Brazil, an interesting context to investigate relevant issues of the theoretical and practical contribution of IS strategy in an uncertain environment aggravated by the turbulence of economic crisis. Brazil's GDP was negative in 2015 and 2016 (IBGE, 2016, 2017), and presents different levels of turbulence and environmental uncertainty than countries with a stable economy (Yayla \& $\mathrm{Hu}, 2012$ ). Thus, the study sought to fill open gaps in the IS strategy literature and n Practice theory, contributed with new insights into the relationship between SIS and BS and performance, enabling strategy-as-practice in organizations and examining the implications of environmental uncertainty of dynamism, heterogeneity and hostility separately and for high and low levels. Post hoc analysis results contributed to identify heterogeneity not observed in the proposed model, the nonlinear causality of latent variables in SIS and BS relationship, as well as to the understanding SIS's contribution incorporated into the BS process (Kohli \& Grover, 2008), confirming the positioning of IS strategizing (Marabelli \& Galliers, 2017; Peppard et al., 2014; Whittington, 2014; Yoshikuni \& Albertin, 2018a). Hence, a theoretical approach incorporating previous knowledge was employed, and therefore, contributing to the cumulative research flow in the IS field.

\section{Theory Development}

\section{Strategic Information Systems}

Academic studies on the use of IS to support business strategies have increased over the years (Arvidsson et al., 2014; Yolande E. Chan, Denford, \& Jin, 2016; Marabelli \& Galliers, 2017; Newkirk \& Lederer, 2006; Teo \& King, 1997), contributing to productivity, innovation, competitive advantage and organization growth and performance (Y.E. Chan, Sabherwal, \& Thatcher, 2006; Y. Chen et al., 2014; Yoshikuni \& Albertin, 2018a). IS strategy empowers the organization to capture, store, transfer and display information to support strategic decision-making (Yolande E. Chan et al., 2016; D. Q. Chen et al., 2010), to address the challenges of environmental turbulence, understand the various external actors and utilize the intelligence of markets and society for innovation in complex and dynamic environments (Merali et al., 2012).

Given the importance of IS strategy approaches (process and content, desired impact and alignment, D. Y. Chen et al, 2010), and the impracticability of examining all in an empirical study, it was decided to focus on SIS to support the process and BS content in the context of environmental uncertainty, adopting the IS strategizing definition (Marabelli \& Galliers, 2017; Peppard et al., 2014; Whittington, 2014; Yoshikuni \& Albertin, 2018b) in the stages of strategic planning process, strategic awareness, environmental analysis, development and BS execution and monitoring (D. Q. Chen et al., 2010; Newkirk \& Lederer, 2006; Singh, Watson, \& Watson, 2002). SIS was approached as a set of IS/IT (information technology) applications that involve current processes and practices of the strategy (D. Q. Chen et al., 2010; Merali et al., 2012), contributing to a holistic, interactive, decentralized, knowledge and learning dynamic vision of practitioners of the strategy-as-practice (Marabelli \& Galliers, 2017; Peppard et al., 2014; Whittington, 2014; Yoshikuni \& Albertin, 2018a).

\section{Business strategy}

Several approaches are used in strategy theory to conceptualize the firm's strategy (Mintzberg et al., 2009). "Strategic planning" received considerable emphasis and research conducted in the past decades $(1960 \mathrm{~s}, 70 \mathrm{~s}, 80 \mathrm{~s}$ and 90s) investigated strategic planning in stable and predictable environments, which driven by the increase of environmental turbulence has changed in the present (Grant, 2003).

The main dimensions to measure a strategic planning construct correspond to strategic objectives disseminations (Hill et al., 2014; Kaplan \& Norton, 2008; Yoshikuni \& Albertin, 2014) at different organization levels (Bromiley \& Rau, 2014; Dameron, Lê, \& Lebaron, 2015; Heyden, Fourn, Koene, Werkman, \& Ansari, 2017), scanning the external environment (Hill et al., 2014; Kaplan \& Norton, 2008; Porter, 1986), identifying positive and negative factors (Davenport, Harris, \& Morison, 2010; Jarzabkowski \& Kaplan, 2015; Yoshikuni \& Albertin, 2018a), selecting and formulating strategies and plans (Babafemi, 2015; Dameron et al., 2015; Grant, 2003; Heyden et al., 2017) in a continuous cycle of simulation and evaluation of strategic projects (Kaplan \& Norton, 2008; Yoshikuni \& Albertin, 2018a), executing the strategy (Grant, 2003; Mintzberg et al., 2009) and translated by employees (Dameron et al., 2015; Grant, 2003; Kaplan \& Norton, 2008; Yoshikuni \& Albertin, 2018a), and controlling and following-up the strategy (Dameron et al., 2015; Grant, 2003; Whittington, 2014) to measure achievements versus those planned (Babafemi, 2015; Heyden et al., 2017; Kaplan \& Norton, 1992).

Recent studies have investigated strategic planning evolution, with the strategy-as-practice approach, which occurs through the intense participation of employees, generating flexibility, agility and understanding of the dynamic and complex process of executing the BS (Bromiley \& Rau, 2014; Chin, Thatcher, Wright, \& Steel, 2013; Dameron et al., 2015; Marabelli \& Galliers, 2017; Peppard et al., 2014; Whittington, 2014), characterized by the dynamic and complex realization of everyday strategic practices (Kaplan \& Norton, 2008; Yoshikuni \& 
Albertin, 2018a), fusing prescriptive strategy practices with new ways of gaining and maintaining differential competitive advantage (Marabelli \& Galliers, 2017; Mintzberg et al., 2009).

\section{Corporate Performance}

$\mathrm{CP}$ measurement was broadened to assess the multiple dimensions of organizational effectiveness (Mithas, Ramasubbu, \& Sambamurthy, 2011; Mostaghel, Oghazi, Beheshi, \& Hultman, 2015; Yoshikuni \& Albertin, 2018a). Several researchers have considered the Balanced Scorecard (BSC) (Kaplan \& Norton, 1992, 2008) as an effective and comprehensive tool for $\mathrm{CP}$ based on financial success that measures organizational growth and productivity. It converts the firm's tangible and intangible assets in increased shareholder value (Atkinson, Kaplan, Matsumura, \& Young, 2011; Park, Lee, \& Chae, 2017b; Yoshikuni \& Albertin, 2018b), in the client performance measured by the value creation and market delivery (Bento, Bento, \& White, 2013; Mostaghel et al., 2015; Yoshikuni \& Albertin, 2017), in the business process performance measured by the efficiency and effectiveness of value chain activities that transform assets into benefits for customers and shareholders (Kaplan \& Norton, 1992; Park, Lee, \& Chae, 2017a; Sen, Bingol, \& Vayway, 2017), and in the organizational perspective of learning and growth by alignment of the intangible assets that are consumed to create organizational value (Albertin \& Albertin, 2012; Bento et al., 2013; Kaplan \& Norton, 2008; Mithas et al., 2011; Yoshikuni \& Albertin, 2017).

\section{Environmental uncertainty}

Environmental uncertainty has been extensively investigated in BS theories (Grant, 2003; Lumpkin \& Dess, 2001; Mintzberg et al., 2009; Schilke, 2014; Whittington et al., 2017; Yoshikuni \& Albertin, 2018b) as contextual factor influencing the use of IS applications as a mechanism that enables the firm to face the complexity, dynamism, uncertainty and unpredictability of social, political and economic systems (Merali et al., 2012; Newkirk \& Lederer, 2006; Ray, Wu, \& Konana, 2009; Yayla \& Hu, 2012), also characterized by dynamism, heterogeneity and hostility (Miller \& Friesen, 1983).

Heterogeneity is identified by the complexity and diversity of external environmental factors that influence the organization's market and production processes ((Mao, Liu, \& Zhang, 2014; Miller \& Friesen, 1983). Market turbulences are measured by changes in evaluation, behavior and preferences of the new and current customers (Y. Chen et al., 2014; Wilden \& Gudergan, 2015; Yayla \& Hu, 2012). Dynamism is measured by market volatility (Newkirk \& Lederer, 2006; Schilke, 2014), i.e., by the high changing rates of the external environment that generate difficulties to predict future situations and events (Y. Chen et al., 2014; Lumpkin \& Dess, 2001; Merali et al., 2012; Ray et al., 2009). Hostility is measured by resources scarcity and the intensity by which the actors in a particular market compete for these (Y. Chen et al., 2014; Lumpkin \& Dess, 2001; Mao et al., 2014). Turbulence index corresponds to the degree of competition in a particular market (Newkirk \& Lederer, 2006; Wilden \& Gudergan, 2015).

\section{Research Model and Hypotheses}

The research conceptual model below illustrates our hypotheses and assumes that the impact of SIS on corporate performance is mediated by business strategy (Figure 1). Therefore, a strong SIS is hypothesized to promote business strategy, enabling greater flexibility of strategy process and a repertory of options for strategy content, which is fundamental condition for gain corporate performance. Once IT/IS empirical studies debate about the external conditions that favor the realization of the IT business value from business strategy and corporate performance (Mikalef \& Pateli, 2017; Yoshikuni \& Albertin, 2018a), these study also investigated the moderation of uncertainty environment in the relationship of conceptual model.

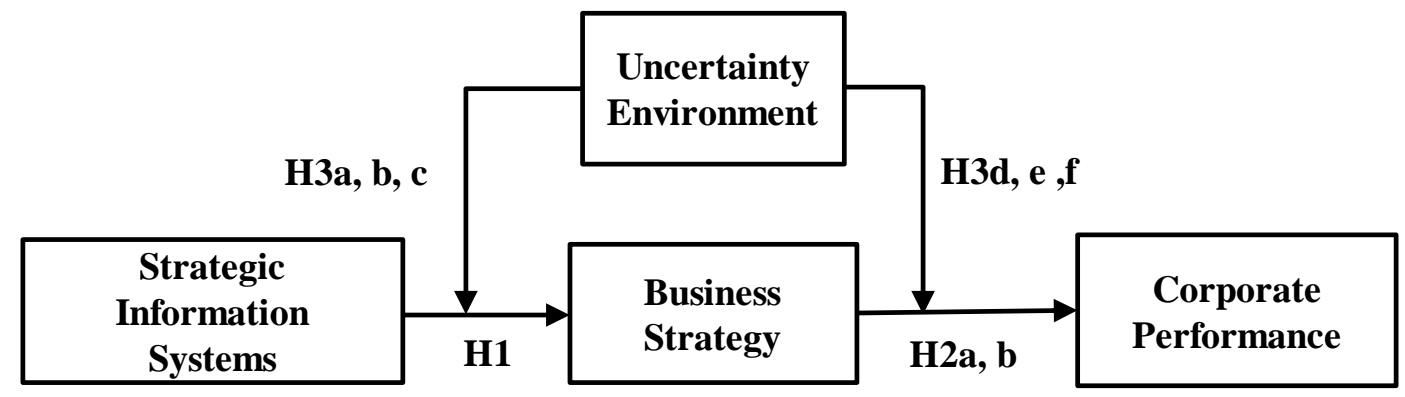

Figure 1. Conceptual model of the influence of business strategy mediation on the relationship between SIS and $\mathrm{CP}$ moderated by the environmental uncertainty 


\section{Strategic Information Systems and Business Strategy}

Communication, integration and cooperation, without local boundaries, enables awareness of strategic guidelines through SIS (D. Q. Chen et al., 2010; A.H. Segars \& Grover, 1999; A.H. Segars, Grover, \& Teng, 1998), generating effective understanding of these, objectives and priorities for all organizational levels (Karpovsky \& Galliers, 2015). SIS promote flexibility and agility, i.e., such as adaptability, agility, resilience, robustness, versatility, and absorption (Pavlou \& El Sawy, 2010). to map positive and negative external factors (Dameron et al., 2015; Newkirk \& Lederer, 2006; Xue, Ray, \& Sambamurthy, 2012; Yoshikuni \& Albertin, 2018a) through the application of business intelligence and big data that collect and analyze a large volume of data and information (D. Q. Chen et al., 2010; George, Haas, \& Pentland, 2014; Marabelli \& Galliers, 2017), reducing the environment analysis cycle, integrating data and market information (Grant, 2003), reducing decision making time (Rouhani, Ashrafi, Ravasan, \& Afshari, 2016; Shollo \& Galliers, 2016), and formulating strategic actions to capture opportunities and mitigate threats (Kaplan \& Norton, 2008; Sabherwal \& Chan, 2001; Xue et al., 2012). The organization enables analytical capacity by SIS to structure a large volume of data and information and to translate it into strategic knowledge (Davenport et al., 2010; Rouhani et al., 2016; Yoshikuni \& Albertin, 2018a, 2017), formulate and implement BS action plans (Kearns \& Sabherwal, 2006) of innovation and productivity (Johnson \& Lederer, 2013; Leidner et al., 2011; Marabelli \& Galliers, 2017; Merali et al., 2012; Shollo \& Galliers, 2016). Monitoring and controlling strategic planning objectives and goals are enabled by SIS by collecting, integrating, consolidating data and information to be discussed in face-to-face meetings of employees, superiors, subordinates and peers, disseminating and strengthening the firm's accountability (Davenport et al., 2010; Yoshikuni \& Albertin, 2018a).

In this regard, SIS empowered the organization to successfully execute strategic planning (D. Q. Chen et al., 2010; Newkirk \& Lederer, 2006; Albert H. Segars \& Grover, 1998; Singh et al., 2002; Yoshikuni \& Albertin, 2018a) in a comprehensive holistic system that enables the firm to develop an effective participatory and decentralized work of thinking, analyze, select, implement and monitor the BS supported by the various IS, postulating the following hypothesis:

\section{H1: The use of SIS enables BS with flexibility and agility.}

\section{Business Strategy and Corporate Performance}

Over the last few decades, theoretical and empirical studies have shown that strategic planning improves CP by aligning its operations towards the implementation of common strategic objectives (Anwar \& Hasnu, 2016; Kaplan \& Norton, 1992, 2008; Song, Zhao, Arend, \& Im, 2015; Whittington et al., 2017). Theoretical studies on IS/IT value creation investigated by Melville et al. (2004) and Kohli and Grover (2008) demonstrated that SIS precedes and incorporates BS processes by providing indirect effects to $\mathrm{CP}$. Other empirical studies showed the various benefits delivered in strategy mediation in the relationship between SIS and CP (Yolande E. Chan et al., 2016; Kearns \& Sabherwal, 2006; Kim, Shin, Kim, \& Lee, 2011; Yoshikuni \& Albertin, 2018a, 2017). Thus, the following hypotheses are highlighted:

\section{H2a: $B S$ positively influences $C P$.}

H2b: $B S$ mediates the relationship between SIS and CP.

\section{Environmental Uncertainty, Strategic Information Systems and Business Strategy}

Over the past few years, studies of the indirect effects of environmental uncertainty on SIS have been intensified (Y. Chen et al., 2014; Leidner et al., 2011; Mao et al., 2014; Mikalef \& Pateli, 2017; Newkirk \& Lederer, 2006; Yoshikuni \& Albertin, 2018a). Teo \& King (1997) developed one of the first studies on the effects of heterogeneity, dynamism and hostility in the use of IS supporting business strategies. Newkirk and Lederer's (2006) investigations have empirically demonstrated that using SIS in uncertain environments of dynamism, heterogeneity and hostility have contributed organizations to respond to unpredictable challenges and events. Recent studies have shown that SIS enable organization in high uncertain environments to develop organizational capacity to analyze and make agile decisions (Y. Chen et al., 2014; Mao et al., 2014), enabling competitive strategies and influencing performance (Y.E. Chan et al., 2006).

Kearns \& Sabherwal (2006) found that IS incorporation in strategic planning enabled the organization to face the intensity of market diversity, and the greater the diversity, the greater the firm's need to obtain information to understand and take decisions. Thus, in a heterogeneous environment, SIS enable the organization's capacity to coordinate, disseminate, collect, analyze, implant and effectively follow the BS, formulating the following hypothesis:

H3a: The relationship between SIS and BS is moderated by the environmental uncertainty of high and low heterogeneity. 
Rapidly changing environments raise the organization's challenge to develop agile BS to effectively deal with dynamism complexity (Y.E. Chan et al., 2006; Mikalef \& Pateli, 2017). Recent studies have shown that SIS enable the organization to quickly and flexibly respond to the demands arising from dynamism uncertainty (Y. Chen et al., 2014; Pavlou \& El Sawy, 2010; Yoshikuni \& Albertin, 2018a). Merali et al (2012) confirmed the effectiveness of SIS in supporting adaptation or transformation strategies for firms to remain competitive in rapidly changing environments. Chen et al. (2014) identified that SIS contribute to the rapid information availability for innovation and productivity strategy development by mapping new opportunities, capturing market information, and analyzing customer and competitor data. Thus, dynamism uncertainty could positively moderate the relationship between SIS and BS.

H3b: The relationship between SIS and BS is moderated by the environmental uncertainty of high and low dynamism.

Resources scarcity and increasing competition for these resources increase the competitive turbulence (Mao et al., 2014; Yoshikuni \& Albertin, 2018a). High hostility rates restrict resource use and may negatively impact collaboration, participation, communication, analysis, formulation and strategic decision making (Y. Chen et al., 2014). However, hostility requires greater organization ability to efficiently and effectively use the limited organizational resources, and SIS can contribute to the success of the strategic planning process by enabling the organization to gather, analyze data and information on the availability and location of resources and the best way to obtain and use them (Newkirk \& Lederer, 2006). Thus, it can be concluded that:

H3c: The relationship between SIS and BS is moderated by the environmental uncertainty of high and low hostility.

\section{Environmental Uncertainty, Business Strategy and Corporate Performance}

Turbulence increases organizations' efforts to look forward, to project scenarios and future situations into shorter planning horizons (Whittington et al., 2017). The complexity and dynamism of the digital age challenge organizations to develop flexibility and agility to achieve higher performance through new strategic e-business strategic planning practices (Lipitakis \& Phillips, 2015). Turbulence and uncertainty pressured contemporary strategic planning to develop mechanisms to respond to the demands of this environment and achieve organizational effectiveness (Grant, 2003; Whittington, 2014; Yoshikuni \& Albertin, 2018a). Thus, it was considered that:

H3d: The relationship between $B S$ and $C P$ is moderated by the environmental uncertainty of high and low heterogeneity.

H3e: The relationship between $B S$ and $C P$ is moderated by the environmental uncertainty of high and low dynamics.

H3f: The relationship between $B S$ and $C P$ is moderated by the environmental uncertainty of high and low hostility.

\section{Methodological Approach}

The sample was selected from Brazilian firms from the directory provided by the Center for Applied Information Technology (GVcia) of FGV. Target respondents were senior business executives with appropriate knowledge of the firm's strategic business and IT/IS processes. Executives were asked to consult other members of their firm to obtain information about which they were not highly knowledgeable (Mikalef \& Pateli, 2017). The survey was sent to 1089 organizations from which $139(13 \%)$ of the questionnaires were answered. The platform was configured to restrict missing data fill errors.

The sample showed to be 10 times bigger than the structural paths number that predict a particular reflexive construct (Hair, Sarstedt, Ringle, \& Gudergan, 2018); however, a more rigorous test of the minimum study sample size was performed using the $G^{*}$ Power v.3.1.9.2 software (Faul, Erdfelder, Lang, \& Buchner, 2007), with a median effect size $\left[\mathrm{f}^{2}\right]$ of 0.15 and with statistical power of not less than 0.80 (Hair et al., 2018; Ringle, Bido, \& Da Silva, 2014), recommending a minimum sample size of 43 cases. Demographic data of respondents on behalf of their respective organizations show that $28 \%$ hold presidential, director and superintendent positions, $42 \%$ were managers and coordinators and 30\% were decision-makers. Table 1 shows the distribution of companies in the sample. 
Table 1. Types of participating firms

\begin{tabular}{lclc}
\hline \multicolumn{1}{c}{ Sector } & & \multicolumn{2}{c}{$\begin{array}{c}\text { Number of employees } \\
\text { (Size) }\end{array}$} \\
\hline Agrobusiness & $6 \%$ & $\leq 9$ & $4 \%$ \\
Manufacturing & $30 \%$ & $10-49$ & $9 \%$ \\
Services & $64 \%$ & $50-99$ & $12 \%$ \\
& & $100-249$ & $9 \%$ \\
& & $250-499$ & $9 \%$ \\
& & $\geq 500$ & $58 \%$ \\
\hline
\end{tabular}

\section{Research Findings}

After evaluation of the descriptive statistics of the demographic variables, scale clearance followed through the confirmatory factorial analysis (convergent validity, discriminant validity and reliability).

\section{Measurement model}

Dimensions were defined from theoretical reference (see Table 2) and the survey instrument was developed to collect data to validate the main constructs and test the research hypotheses. It maintained for confirmatory factor analysis, the constructs poses reflective indicators and were connected to each other, assuming they are correlated (Hair, Hult, Ringle, \& Sarstedt, 2016). The 7-point Likert scale was used, varying from 1 (totally disagree) to 7 (totally agree) to evaluate the constructs. The validated scale, with the items used - the constructs, the scale assertions (variables/indicators) and their factorial loads - can be found in the survey instrument with the first author.

Table 2. Measures and sources of variables used in the analyses

\begin{tabular}{|c|c|c|}
\hline Variables & Measures & Sources \\
\hline $\begin{array}{l}\text { Strategic } \\
\text { Information } \\
\text { Systems }\end{array}$ & IS support BS & Yoshikuni \& Albertin (2018a) \\
\hline Business Strategy & Strategic planning process & $\begin{array}{l}\text { Grant (2003) and Hill, Jones and } \\
\text { Schilling (2014) }\end{array}$ \\
\hline $\begin{array}{l}\text { Corporate } \\
\text { Performance }\end{array}$ & $\begin{array}{l}\text { Financial } \\
\text { Customer } \\
\text { Business process } \\
\text { Learning and growth }\end{array}$ & Kaplan and Norton $(1992,2008)$ \\
\hline $\begin{array}{l}\text { Enviromental } \\
\text { Uncertainty }\end{array}$ & $\begin{array}{l}\text { Hostility } \\
\text { Dynamism } \\
\text { Heterogeneity }\end{array}$ & $\begin{array}{l}\text { Mikalef \& Pateli (2017), Miller \& } \\
\text { Friesen (1983) and Yayla \& Hu } \\
\text { (2012) }\end{array}$ \\
\hline Control Variables & $\begin{array}{l}\text { Size } \\
\text { Sector }\end{array}$ & $\begin{array}{l}\text { Melville, Kraemer, \& Gurbaxani } \\
\text { (2004), Chan et al. }(2016,2006) \\
\text { and Sabherwal \& Chan }(2001)\end{array}$ \\
\hline
\end{tabular}

The factorial load and the convergent validity of the constructs were performed and the items were above 0.50 , confirming an adequate extracted mean variance (Hair, Sarstedt, Matthews, \& Ringle, 2016). The discriminant validity was verified by observing the values on the diagonal (square root of the extracted mean variance) and these were higher than the values outside the diagonal (correlations) (Hair, Hult, et al., 2016). Reliability was adequate, with composite reliability values higher than 0.7 (Table 3) (Hair, Hult, et al., 2016). 
Table 3. Correlations matrix between constructs

\begin{tabular}{|c|c|c|c|c|c|c|c|c|c|}
\hline Latent variables & 1 & 2 & 3 & 4 & 5 & 6 & 7 & 8 & 9 \\
\hline 1 - Strategic IS & $\mathbf{0 . 8 5}$ & & & & & & & & \\
\hline 2 - Business strategy & 0.70 & 0.81 & & & & & & & \\
\hline 3 - Financial performance & 0.37 & 0.50 & 0.92 & & & & & & \\
\hline 4 - Customer performance & 0.34 & 0.54 & 0.54 & 0.75 & & & & & \\
\hline 5 - Business process performance & 0.54 & 0.64 & 0.54 & 0.62 & 0.75 & & & & \\
\hline 6 - Learning and growth performance & 0.38 & 0.60 & 0.41 & 0.53 & 0.65 & 0.74 & & & \\
\hline 7 - Heterogeneity & 0.20 & 0.33 & 0.13 & 0.23 & 0.35 & 0.13 & 0.77 & & \\
\hline 8 - Dynamism & 0.17 & 0.14 & 0.12 & 0.13 & 0.27 & 0.19 & 0.36 & 0.76 & \\
\hline 9 - Hostility & $-0.23-$ & 0.21 & -0.16 & -0.12 & -0.08 & -0.06 & 0.12 & 0.25 & 0.74 \\
\hline AVE & 0.72 & 0.65 & 0.85 & 0.56 & 0.56 & 0.55 & 0.59 & 0.58 & 0.54 \\
\hline Composite reliability & 0.93 & 0.90 & 0.94 & 0.79 & 0.79 & 0.78 & 0.80 & 0.81 & 0.78 \\
\hline Means & 4.56 & 4.77 & 4.56 & 5.27 & 4.83 & 4.97 & 4.67 & 3.68 & 3.89 \\
\hline Standard deviation & 1.30 & 1.01 & 1.61 & 0.93 & 1.13 & 1.11 & 1.41 & 1.13 & 1.41 \\
\hline Variance coefficient & 0.28 & 0.21 & 0.35 & 0.18 & 0.23 & 0.22 & 0.30 & 0.31 & 0.36 \\
\hline
\end{tabular}

Structural Model

The model implicates a complex operationalization as it involves the evaluation of the moderation effects of environmental uncertainty and control variables, and inclusion of a latent variable to remove the bias from the MLMV (measured latent marker variable). As recommended by Chin, Thatcher, Wright and Steel (2013), four items designed to have the lowest possible logical correlation with other constructs under investigation were included to control the bias of the common method (Table 4). The analysis was based on the cases of Table 5 and the results are commented in the following sections.

Table 4. Indicators used for MLMV analysis

MLMV_1: I always conquer my goals.

MLMV_2: My dream is to have my own business.

MLMV_3: I like the hot weather.

MLMV_4: I always imagine what my life will be like in the future.

Table 5. Standardized regression coefficients of the structural models with MLMV items

\begin{tabular}{clrrrrr}
\hline \multirow{2}{*}{ Case } & \multicolumn{1}{c}{ Structural model } & $\begin{array}{c}\text { Path } \\
\text { coefficient }\end{array}$ & $\begin{array}{c}\text { Standard } \\
\text { error }\end{array}$ & t value & p value & $\mathrm{R}^{2}$ \\
\hline \multirow{2}{*}{1} & SIS -> Corporate performance & 0.0892 & 0.098 & 0.912 & 0.362 & \\
& BS -> Corporate performance & 0.5399 & 0.109 & 4.938 & 0.000 & $45.3 \%$ \\
& MLMV -> Corporate performance & 0.4063 & 0.136 & 0.091 & 1.493 & \\
\hline \multirow{2}{*}{2} & SIS -> Business strategy & 0.6327 & 0.050 & 12.709 & 0.000 & \multirow{2}{*}{$57.0 \%$} \\
& MLMV -> Business strategy & 0.3016 & 0.054 & 5.636 & 0.000 & \\
\hline
\end{tabular}

Legend: Business strategy (BS) and Strategic information systems (SIS).

Note 1. Significance was estimated by bootstrap with $\mathrm{N}=139$ cases and 1000 replicates in SmartPLS 3.2.6.

The relationships between SIS and CP, and SIS and BS with the inclusion of the MLMV in cases 1 and 2 (Table 5 ), presented statistical significance ( $p$ value $<0.001$ ), from which the need to operationalize the model without the inclusion of the MLMV (Table 6) was noticed, and the structural coefficients of the model "without the inclusion of the MLMV" and "with the inclusion of the MLMV" were compared.

Table 6. Standard regression coefficients of the structural models without MLMV items

\begin{tabular}{|c|c|c|c|c|c|c|}
\hline Case & Structural model & $\begin{array}{c}\text { Path } \\
\text { coefficient }\end{array}$ & $\begin{array}{c}\text { Standard } \\
\text { error }\end{array}$ & t value & p value & $\mathbf{R}^{2}$ \\
\hline \multirow{2}{*}{ 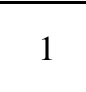 } & SIS -> Corporate performance & 0.062 & 0.094 & 0.660 & 0.509 & \multirow{2}{*}{$43.90 \%$} \\
\hline & BS -> Corporate performance & 0.532 & 0.081 & 6.540 & 0.000 & \\
\hline 2 & SIS -> Business strategy & 0.698 & 0.046 & 15.296 & 0.000 & $48.70 \%$ \\
\hline
\end{tabular}


According to Hair et al (2018), to compare the path coefficients differences between the structural models, the use of multigroup analysis (PLS-MGA) is recommended. Table 7 shows the result for the relations of latent variables and did not present statistically significant differences between the path effects ( $\mathrm{p}$ value $>0.05$ ). The sample did therefore not present bias of the common collection method, and structural model of Table 3 was used for analysis of hypothesis $\mathrm{H} 1$ and $\mathrm{H} 2$, showing that the $\mathrm{R} 2$ values in all relations presented a great effect and provided a measure of structural model quality, as suggested by Ringle et al. (2014).

Table 7. Comparison of the structural coefficients with and without inclusion of the MLMV

\begin{tabular}{lrrrrrrr}
\hline & \multicolumn{2}{c}{ With MLMV } & \multicolumn{2}{c}{ Without MLMV } & \multicolumn{2}{c}{ With MLMV vs Without MLMV } \\
Relationship between variables & $\begin{array}{c}\text { Path } \\
\text { Coefficient }\end{array}$ & Standard error & $\begin{array}{c}\text { Path } \\
\text { Coefficient }\end{array}$ & $\begin{array}{c}\text { Standard } \\
\text { error }\end{array}$ & $|\beta 1-\beta 2|$ & t value & $p$ value \\
\hline SIS -> Corporate performance & 0.0892 & 0.098 & 0.062 & 0.094 & 0.028 & 0.204 & 0.839 \\
BS -> Corporate performance & 0.5399 & 0.109 & 0.532 & 0.081 & 0.008 & 0.057 & 0.955 \\
SIS -> Business strategy & 0.6327 & 0.050 & 0.698 & 0.046 & 0.065 & 0.971 & 0.333 \\
\hline
\end{tabular}

Hypotheses H1 and H2a supported (value p < 0.001) that SIS influence the BS, and the BS influences the CP.

As recommended by Hair, Hulf et al (2016), the indirect effects of BS mediation on the relationship between SIS and $\mathrm{CP}$ through VAF (variance accounted for) result was verified, as it was totally mediated by the BS (direct effect $=0.062$, total effect $=0.433$, indirect effect $=86 \%, \mathrm{VAF}=14 \%)$ with statistical significance $(\mathrm{p}$ value $<$ 0.001 ), thus supporting the $\mathrm{H} 2 \mathrm{~b}$ hypothesis.

The influence of environmental uncertainty through the variables of heterogeneity, dynamism and hostility, and control variables in the variables dependent on BS and CP (Carlson \& Wu, 2012) were also verified. The PLS-MGA method was used to analyze the effect of environmental uncertainty. Subgroups classified as "high" and "low" presence of heterogeneity, dynamism and hostility dimensions (Newkirk \& Lederer, 2006; Yayla \& $\mathrm{Hu}, 2012$ ) were created and investigated the predictive power of SIS and BS on the dependent variables, comparing the path effects in the relations between exogenous and endogenous variables, according to Tables 8 , 9 and 10.

Table 8. Comparison of structural coefficients of low (41 cases) and high (98 cases) heterogeneity

\begin{tabular}{|c|c|c|c|c|c|c|c|}
\hline \multirow{2}{*}{ Relationship between variables } & \multicolumn{2}{|c|}{$\begin{array}{l}\text { Low heterogeneity } \\
\text { (41 cases) }\end{array}$} & \multicolumn{2}{|c|}{$\begin{array}{l}\text { High Heterogeneity } \\
\text { (98 cases) }\end{array}$} & \multicolumn{3}{|c|}{ Low vs High } \\
\hline & $\begin{array}{c}\text { Path } \\
\text { Coefficient }\end{array}$ & Standard error & $\begin{array}{c}\text { Path } \\
\text { Coefficient }\end{array}$ & $\begin{array}{l}\text { Standard } \\
\text { error }\end{array}$ & $|\beta 1-\beta 2|$ & $\mathrm{t}$ value & $\mathrm{p}$ value \\
\hline SIS -> Corporate performance & 0.086 & 0.141 & 0.064 & 0.141 & 0.023 & 0.093 & 0.926 \\
\hline BS -> Corporate performance & 0.744 & 0.108 & 0.539 & 0.144 & 0.206 & 0.885 & 0.377 \\
\hline SIS -> Business strategy & 0.564 & 0.120 & 0.754 & 0.039 & 0.191 & 1.969 & 0.050 \\
\hline
\end{tabular}

The subgroup of low heterogeneity consisted of 41 firms and the high of 98 firms. The relationship between SIS and the BS presented a difference in path coefficients and statistical significance ( $\mathrm{p}$ value $<0.05$ ) and supported the H3a hypothesis. The H3d hypothesis did not present statistical significance and was not supported when comparing the path effects in the relationship between strategy and CP ( $\mathrm{p}$ value $=0.377)$.

Dynamic and hostility variables were moderated in the relationships between SIS and BS, and BS and CP, and no statistical significance was found (p value > 0.05) for these. Hence, hypotheses H3b, H3c, H3e and H3f were not supported (Tables 9 and 10).

Table 9. Comparison of structural coefficients of low and high dynamism cases

\begin{tabular}{|c|c|c|c|c|c|c|c|}
\hline \multirow{2}{*}{ Relationship between variables } & \multicolumn{2}{|c|}{$\begin{array}{l}\text { Low dynamism } \\
\text { (84 cases) }\end{array}$} & \multicolumn{2}{|c|}{$\begin{array}{l}\text { High dynamism } \\
\text { (55 cases) }\end{array}$} & \multicolumn{3}{|c|}{ Low vs High } \\
\hline & $\begin{array}{c}\text { Path } \\
\text { Coefficient }\end{array}$ & Standard error & $\begin{array}{c}\text { Path } \\
\text { Coefficient }\end{array}$ & $\begin{array}{l}\text { Standard } \\
\text { error }\end{array}$ & $|\beta 1-\beta 2|$ & t value & $\mathrm{p}$ value \\
\hline SIS -> Corporate performance & 0.078 & 0.099 & 0.038 & 0.239 & 0.040 & 0.175 & 0.861 \\
\hline BS -> Corporate performance & 0.614 & 0.104 & 0.611 & 0.217 & 0.003 & 0.015 & 0.988 \\
\hline SIS -> Business strategy & 0.648 & 0.063 & 0.786 & 0.057 & 0.139 & 1.545 & 0.124 \\
\hline
\end{tabular}


Table 10. Comparison of structural coefficients of low and high hostility

\begin{tabular}{|c|c|c|c|c|c|c|c|}
\hline \multirow{2}{*}{ Relationship between variables } & \multicolumn{2}{|c|}{$\begin{array}{c}\text { Low hostility } \\
\text { (82 cases) }\end{array}$} & \multicolumn{2}{|c|}{$\begin{array}{c}\text { High Hostility } \\
\text { (57 cases) }\end{array}$} & \multicolumn{3}{|c|}{ Low vs High } \\
\hline & $\begin{array}{c}\text { Path } \\
\text { Coefficient }\end{array}$ & Standard error & $\begin{array}{c}\text { Path } \\
\text { Coefficient }\end{array}$ & $\begin{array}{l}\text { Standard } \\
\text { error }\end{array}$ & $|\beta 1-\beta 2|$ & $\mathrm{t}$ value & $\mathrm{p}$ value \\
\hline SIS -> Corporate performance & 0.1459 & 0.123 & 0.039 & 0.153 & 0.185 & 0.959 & 0.339 \\
\hline BS -> Corporate performance & 0.5616 & 0.123 & 0.675 & 0.142 & 0.114 & 0.605 & 0.546 \\
\hline SIS -> Business strategy & 0.7257 & 0.056 & 0.653 & 0.059 & 0.073 & 0.875 & 0.383 \\
\hline
\end{tabular}

IT/IS expenses of Brazilian organization keep increasing, and as evidenced by the annual research carried out by the Getulio Vargas Foundation (FGV), the services sector spent 11\% and manufacturing $4.5 \%$ of their net sales in 2016 in this (Meirelles, 2018). Thus, this investigation sought to study the influences, through control variables of the characteristics of the organization (Melville, Kraemer, \& Gurbaxani, 2004), its sector and its size by the number of employees (Y.E. Chan et al., 2006; Yolande E. Chan et al., 2016) in relation to SIS, BS and CP (Sabherwal \& Chan, 2001). The influence of the control variables - size and sector - in the relations of the latent model variables was also evaluated and compared with the path coefficients using the PLS-MGA method (Hair, Hult, et al., 2016; Yoshikuni \& Albertin, 2017). Subgroups of firms with <499 and >500 employees were created and it was identified that the relationships between SIS and BS, and BS and CP, are moderated by the firm's size, showing a statistically significant difference of respectively $0.391(50 \%)$ for the relation between BS and CP (p value <0.05). However, the direct relationship between SIS and CP for both groups of <499 and >500 employees did not present statistical significance $(\mathrm{p}$ value $=0.198, \mathrm{p}$ value $=0.071)($ Table 11$)$.

Table 11. Comparison of the structural coefficients of the firm's size control variable

\begin{tabular}{|c|c|c|c|c|c|c|c|}
\hline \multirow{2}{*}{ Relationship between variables } & \multicolumn{2}{|c|}{$\begin{array}{c}\text { Less than } 499 \\
\text { employees (59 cases) }\end{array}$} & \multicolumn{2}{|c|}{$\begin{array}{c}\text { More than } 500 \\
\text { employees (80 cases) }\end{array}$} & \multirow{2}{*}{$\begin{array}{l}\text { Less than } 499 \\
\qquad|\beta 1-\beta 2|\end{array}$} & \multicolumn{2}{|c|}{ vs More than 500} \\
\hline & $\begin{array}{c}\text { Path } \\
\text { Coefficient }\end{array}$ & Standard error & $\begin{array}{c}\text { Path } \\
\text { Coefficient }\end{array}$ & $\begin{array}{c}\text { Standard } \\
\text { error }\end{array}$ & & $\mathrm{t}$ value & $\mathrm{p}$ value \\
\hline SIS -> Corporate performance & -0.1492 & 0.116 & 0.242 & 0.134 & 0.391 & 2.126 & 0.035 \\
\hline BS -> Corporate performance & 0.7897 & 0.103 & 0.399 & 0.123 & 0.391 & 2.342 & 0.020 \\
\hline SIS -> Business strategy & 0.6874 & 0.056 & 0.650 & 0.071 & 0.038 & 0.399 & 0.690 \\
\hline
\end{tabular}

The moderation sector was analyzed regarding the relation between exogenous and endogenous variables for the sectors with the highest representation in the sample, manufacturing and service (Table 12). No influence of the sector was identified in the relationship between SIS and BS, and BS and CP (value p>0.05).

Table 12. Comparison of the structural coefficients of the control variable of the industry and service sectors

\begin{tabular}{lrrrrrrrr}
\hline \multirow{2}{*}{ Relationship between variables } & \multicolumn{2}{c}{ Manufacturing (43 cases) } & \multicolumn{2}{c}{ Service (89 cases) } & \multicolumn{3}{c}{ Manufacturing vs Service } \\
& $\begin{array}{c}\text { Path } \\
\text { Coefficient }\end{array}$ & $\begin{array}{c}\text { Standard } \\
\text { error }\end{array}$ & $\begin{array}{c}\text { Path } \\
\text { Coefficient }\end{array}$ & $\begin{array}{c}\text { Standard } \\
\text { error }\end{array}$ & $|\beta 1-\beta 2|$ & t value & p value \\
\hline SIS -> Corporate performance & 0.038 & 0.206 & 0.076 & 0.109 & 0.038 & 0.182 & 0.856 \\
BS -> Corporate performance & 0.5408 & 0.200 & 0.658 & 0.107 & 0.117 & 0.572 & 0.568 \\
SIS -> Business strategy & 0.7386 & 0.062 & 0.677 & 0.061 & 0.062 & 0.639 & 0.523 \\
\hline
\end{tabular}

\section{Post hoc analysis}

A post hoc analysis was carried out in order to guide and direct possible conclusions of the study, structuring it to investigate the presence of unobserved heterogeneity, examine combinations of non-linear causal conditions and the influence of IS strategizing by means of IS moderation product and BS.

The presence of unobserved heterogeneity was realized through Finite Mixture modeling (FIMIX-PLS), identifying the existence of significant differences in structural model relationships between data groups that were not observed by the environmental control and uncertainty variables (Becker, Rai, Ringle, \& Volckner, 2013; Hair, Sarstedt, et al., 2016). The FIMIX-PLS algorithm was run 10 times for segments 1-5 using the Akaike Information Criterion (AIC), modified AIC with factor 3 ( $\mathrm{AIC}_{3}$ ), Bayesian Information Criterion (BIC), Consistent AIC (CAIC), Hannan-Quinn Criterion (HQ) and normed Entropy Statistics (EN) to identify the appropriate targeting solution from appropriate segmentation (Matthews, Sarstedt, Hair, \& Ringle, 2016; Sarstedt, Becker, Ringle, \& Schwaiger, 2011). The information criteria for segment selection (Hair, Hult, et al., 2016; Hair et al., 2018) indicate the two-segment solution as the most appropriate (values coincide for $\mathrm{AIC}_{3}$ and $\mathrm{CAIC}$ together with $\mathrm{ACI}_{3}$ and $\mathrm{BIC}$, in addition to $\mathrm{AIC}_{4}$ and $\mathrm{BIC}, \mathrm{MDL}_{5}$ criterion presented the largest choice of a 
segment and AIC the choice of $<5$ segments, with EN criterion value $>0.5$, Table 13), and the sample size by segment was greater than the minimum size indicated in the structural model of 43 cases (Table 14).

Table 13. Information criteria by segment by FIMIX-PLS

\begin{tabular}{lccccc}
\hline \multirow{2}{*}{ Criterion } & \multicolumn{5}{c}{ Number of solutions } \\
& 1 & 2 & 3 & 4 & 5 \\
\hline AIC & $1,607.342$ & $1,532.897$ & $1,520.447$ & $1,511.244$ & $\mathbf{1 , 5 0 4 . 4 0 7}$ \\
AIC3 & $1,620.342$ & $\mathbf{1 , 5 5 9 . 8 9 7}$ & $1,561.447$ & $1,566.244$ & $1,573.407$ \\
AIC4 & $1,633.342$ & $\mathbf{1 , 5 8 6 . 8 9 7}$ & $1,602.447$ & $1,621.244$ & $1,642.407$ \\
BIC & $1,645.490$ & $\mathbf{1 , 6 1 2 . 1 2 8}$ & $1,640.761$ & $1,672.640$ & $1,706.886$ \\
CAIC & $1,658.490$ & $\mathbf{1 , 6 3 9 . 1 2 8}$ & $1,681.761$ & $1,727.640$ & $1,775.886$ \\
HQ & $1,622.845$ & $\mathbf{1 , 5 6 5 . 0 9 4}$ & $1,569.339$ & $1,576.831$ & $1,586.689$ \\
MDL5 & $\mathbf{1 , 9 0 2 . 0 8 3}$ & $2,145.051$ & $2,450.014$ & $2,758.225$ & $3,068.801$ \\
EN & n/a & $\mathbf{0 . 6 4 7}$ & 0.648 & 0.705 & 0.718 \\
\hline
\end{tabular}

Legend: AIC - Akaike's Information Criterion, $\mathrm{AIC}_{3}$ - Modified AIC with Factor 3, $\mathrm{AIC}_{4}$ - Modified AIC with Factor 4, BIC - Bayesian Information Criteria, CAIC - Consistent AIC, HQ - Hannan Quinn Criterion, $\mathrm{MDL}_{5}$ EN - Entropy Statistic (Normed).

Table 14. Relative size of declining segments per solution

\begin{tabular}{cccccc}
\hline \multirow{2}{*}{$\mathrm{N}^{\circ}$ of solutions } & \multicolumn{5}{c}{ Solutions size } \\
& $\mathrm{S}=1$ & $\mathrm{~S}=2$ & $\mathrm{~S}=3$ & $\mathrm{~S}=4$ & $\mathrm{~S}=5$ \\
\hline 2 & 0.541 & 0.459 & & & \\
3 & 0.373 & 0.342 & 0.285 & & \\
4 & 0.443 & 0.250 & 0.160 & 0.147 & \\
5 & 0.316 & 0.261 & 0.153 & 0.144 & 0.126 \\
\hline
\end{tabular}

Note. The table shows the relative size of the segments in descending order per solution

The simple intersection of FIMIX-PLS segments 1 and 2 was performed with the control and environmental uncertainty variables (Table 15), and the best combination for the environmental uncertainty variables (heterogeneity, dynamism and hostility) and sector (agribusiness, manufacturing and services) was verified for FIMIX-PLS group 1 (numbers in bold in the table). Only the size of the firm by the number of employees for the segmentations of $\leq 9$ and between 50-99 employees proved to be suitable for FIMIX-PLS group 2 (Table 13 numbers in bold). The groupings by the number of cases of the environmental uncertainty variables and sector by segment obtained the result of 80 cases for the FIMIX-PLS group 2, with 58\% of cases, slightly lower than $60 \%$ as recommended by Hair et al (2016). However, the grouping for firm size was unsatisfactory with a total of 53\% of cases. Since the clusters for environmental and sector uncertainty variables presented a slightly satisfactory overlap for explanatory environmental and sector uncertainty variables, the structural models by segment 1 and 2 of FIMIX-PLS (Hair, Hult, (FIMIX-PLS 1, and FIMIX-PLS) were estimated and differences between these models compared by multi-group analysis (PLS-MGA) (Hair, Hult, et al., 2016) (Table 16) with the indicators of the structural models and the identified differences.

Table 15. Simple crossing of moderation variables and FIMIX-PLS segments

\begin{tabular}{cccccccccccccccc}
\hline \multirow{2}{*}{$\begin{array}{c}\text { Soluti } \\
\text { ons }\end{array}$} & \multicolumn{4}{c}{ Environmental Uncertainty } & Heterogeneity & \multicolumn{4}{c}{ Hostility } & \multicolumn{4}{c}{ Dector } & \multicolumn{4}{c}{ Number of employees (Size) } \\
& High & Low & High & Low & High & Low & ness & uring & Service & $<9$ & 10 to & 50 to & 100 to & 250 to & $>500$ \\
\hline 1 & 40 & 19 & 19 & 40 & 20 & 39 & 1 & 18 & 39 & $\mathbf{4}$ & 4 & $\mathbf{1 0}$ & 5 & 4 & 32 \\
2 & $\mathbf{5 8}$ & $\mathbf{2 2}$ & $\mathbf{3 8}$ & $\mathbf{4 2}$ & $\mathbf{3 5}$ & $\mathbf{4 5}$ & $\mathbf{6}$ & $\mathbf{2 5}$ & $\mathbf{5 0}$ & 1 & $\mathbf{8}$ & 6 & $\mathbf{8}$ & $\mathbf{9}$ & $\mathbf{4 8}$ \\
\hline
\end{tabular}


Table 16. Comparison of structural models by segment FIMIX-PLS

\begin{tabular}{|c|c|c|c|c|c|c|}
\hline \multirow{2}{*}{ Structural Model } & \multicolumn{3}{|c|}{ Path coefficients } & \multicolumn{3}{|c|}{$\begin{array}{c}\text { Multigroup analyses (MGA) } \\
\qquad|\beta 1-\beta 2|\end{array}$} \\
\hline & $\begin{array}{l}\text { Original sample } \\
\qquad(\mathrm{OS})\end{array}$ & $\begin{array}{l}\text { Solution } 1 \\
\quad(\mathrm{~S} 1)\end{array}$ & $\begin{array}{l}\text { Solution } 2 \\
\quad(\mathrm{~S} 2)\end{array}$ & OS - S1 & $\mathrm{AO}-\mathrm{S} 2$ & $\mathrm{~S} 1-\mathrm{S} 2$ \\
\hline SIS -> Corporate Performance & 0.062 & 0.038 & 0.100 & 0.024 & 0.038 & 0.062 \\
\hline BS -> Corporate Performance & $0.532 * * *$ & $0.701 * * *$ & $0.533 * * *$ & 0.169 & 0.001 & 0.168 \\
\hline SIS -> Business strategy & $0.698 * * *$ & $0.709 * * *$ & $0.707 * * *$ & 0.012 & 0.009 & 0.003 \\
\hline AVE & + & + & + & + & + & + \\
\hline Composite reliability & + & + & + & + & + & + \\
\hline $\mathrm{R}^{2}$ - Corporate performance & $43.90 \%$ & $53.00 \%$ & $36.90 \%$ & & & \\
\hline $\mathrm{R}^{2}$ - Business strategy & $48.70 \%$ & $50.40 \%$ & $50.00 \%$ & & & \\
\hline
\end{tabular}

Note. $* * * \mathrm{p}$ value $<0.001$; ** $\mathrm{p}$ value $<0.01$; * $\mathrm{p}$ value $<0.5$; Measurement model evaluation criterion fulfilled/not fulfilled in accordance with Hair et al. (2016).

All measures of the model met the common quality standards when comparing the path coefficients between FIMIX-PLS segments 1 and 2 and the original analysis (Hair, Hult, et al., 2016). A difference in the structural coefficients was observed comparing AO-S1 $(0.169 ; 23 \%)$ and S1-S2 $(0.168 ; 23 \%)$ segments, but was not statistically significant ( $\mathrm{p}$ value $>0.05$ ).

The analysis of non-linear causal combinations was performed through the analytical approach of boolean algebra, fuzzy set qualitative comparative analysis (fsQCA) (Fiss, 2011; Frambach, Fiss, \& Ingenbleek, 2016; Ragin, 2008; Woodside, Ko, \& Huan, 2012). According to FIMIX-PLS, the fsQCA was used in both solutions, individually analyzing the relationship between SIS and BS, and the causality of the variables of environmental uncertainty and firm's size were verified. The calibration procedure of fsQCA described by Mikalef and Pateli (2017) to transform the constructs measured on the Likert scale of 7 points in diffuse set, denoting total adhesion (diffuse score $=0.95$ ), total non-association (diffuse score $=0.05$ ) and the crossover point (diffuse score $=0.50$ ) was used. Thresholds of full members are set to values of 6 , cross points to 4.5 and full score of non-members to 3 (Tho \& Trang, 2014). The overall consistency level was 0.928854 , above the recommended 0.75 (Ragin, 2008). Overall coverage of the solution was 0.639021 , showing that the identified configurations represented $64 \%$ adherence to the result in the presence of BS according to Table 17.

Table 17. fsQCA configuration analysis

\begin{tabular}{|c|c|c|c|c|c|c|c|c|}
\hline \multirow{3}{*}{ Causal conditions } & \multicolumn{4}{|c|}{ Solution 1} & \multicolumn{4}{|c|}{ Solution 2} \\
\hline & \multicolumn{4}{|c|}{ Business strategy } & \multicolumn{4}{|c|}{ Business strategy } \\
\hline & Dynamism & Heterogeneity & Hostility & Size & Dynamism & Heterogeneity & Hostility & Size \\
\hline SIS & $\otimes$ & & & 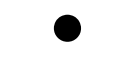 & & & $\otimes$ & \\
\hline $\mathrm{UE}$ and CV & $\otimes$ & 0 & $\otimes$ & $\bullet$ & $\otimes$ & & $\otimes$ & $\otimes$ \\
\hline Raw coverage & 0.819699 & 0.849749 & 0.879800 & 0.774624 & 0.927752 & 0.736812 & 0.865826 & 0.561353 \\
\hline Unique coverage & 0.819699 & 0.849749 & 0.879800 & 0.774624 & 0.927752 & 0.159978 & 0.103211 & 0.294151 \\
\hline Consistency & 0.872114 & 0.862712 & 0.966972 & 0.928000 & 0.803376 & 0.953523 & 0.807163 & 0.824739 \\
\hline \multicolumn{9}{|c|}{ Overall solution coverage: 0.639021} \\
\hline
\end{tabular}

Note. Black circles indicate the presence of a condition, and " $\square$ " indicate its absence. Large circles indicate core conditions; small ones, peripheral conditions. Blank spaces indicate "do not care." Used software fsQCA version 3.0 available www.fsQCA.com

In solution 1, SIS proved to be present in the causality of the BS in the absence of hostility and in the peripheral presence of the firm's size. The absolute presence of heterogeneity in the causality of the BS, as well as the peripheral absence of SIS and dynamism in the causality of the BS were identified. In solution 2, SIS proved necessary the causality of the strategy with the absence of the firm's size; the other solutions presented peripheral absence of environmental uncertainty variables and causality of the BS. 
The strategic alignment measure was created through the moderation between SIS factor scores (Tallon, 2007) and BS, where the product of this measure is equivalent to the strategic alignment of SIS dimension score. According to Sabherwal and Chan (2001) and Tallon (2007), the strategic alignment of SIS was measured as a deviation from the profile that corresponds to the absolute difference of the ideal use (100\%, value 1) of SIS and the actual use of SIS collected and standardized. Small deviation points to tight alignment (fit), while large deviation points to misalignment. To reverse this scale, 1 of each absolute deviation was subtracted. In this way, firms with absolute or perfect alignment received the value of one and below one imply some sense of misalignment. Subsequently, the direct effects of the strategic alignment of SIS on CP were analyzed as "product of moderation" and "profile deviation" (Table 18).

Table 18. Standardized regression coefficients of the SIS strategic alignment structural models

\begin{tabular}{|c|c|c|c|c|c|c|}
\hline Structural model & Method & $\begin{array}{c}\text { Path } \\
\text { coefficient }\end{array}$ & $\begin{array}{c}\text { Standard } \\
\text { error }\end{array}$ & $\mathrm{t}$ value & $\mathrm{p}$ value & $\mathrm{R}^{2}$ \\
\hline \multirow{2}{*}{ SIS alignment -> CP } & Product of moderation & 0.615 & 0.053 & 11.643 & 0.000 & $37.8 \%$ \\
\hline & Perfil desviation & 0.466 & 0.067 & 6.868 & 0.000 & $21.2 \%$ \\
\hline
\end{tabular}

Note 1. Significance was estimated by bootstrap with $\mathrm{N}=139$ cases and 5000 replicates in SmartPLS 3.2.6.

The influence of SIS alignment on CP showed higher direct SIS and BS relations in CP (Table 6), but in the multigroup analysis between the relations did not present statistical significance ( $\mathrm{p}$ value $>0.05$ ) for both cases (product of moderation and profile deviation).

\section{Conclusion, Limitation and Future Study}

This study empirically demonstrated that SIS enabled strategy-as-practice (Arvidsson et al., 2014; Marabelli \& Galliers, 2017), agreeing with other studies conducted in developed countries and stable economic situation (Y.E. Chan et al., 2006). SIS have had a strong influence in enabling flexibility and agility in developing the steps of the strategic planning process to disseminate strategic guidelines, analyze the overall environment, formulate, execute and monitor BS at shorter intervals in a continuous cycle of strategy-as-practice in complex environments.

This research confirmed the strong influence of BS on CP without contribution differences in this relationship in the various levels and dimensions of environmental uncertainty. However, it was observed that small and medium-sized firms (<499 employees) had an effect of 50\% higher contribution in the relation (BS->CP) than large firms (>500 employees), demonstrating the maturity of small and medium-sized enterprises in the use of strategic management practices that until then were only used by large firms (Grant, 2003).

The empirical research of the study confirmed that SIS possess full strategy mediation in relation to CP in complex environments and environmental uncertainty, as evidenced in countries of economic stability (Y.E. Chan et al., 2006; Kim et al., 2011; Tallon, 2007). The study confirmed that in environments of economic turbulence and uncertainty, SIS enabled a broad performance management system that contributes to improve the quality of strategic decisions, coordinates decentralized strategic decision-making and drives the improvement of CP. SIS promote planning time reduction, making strategic decisions more flexible and enabling employees to participate in the strategic planning process.

The study showed that SIS influence the BS in high heterogeneity environments by $33 \%$ more than in low heterogeneity environments. Thus, SIS enabled the organization to face the intensity of market diversity and confirmed to be an effective mechanism to enable the organization's capacity to coordinate, disseminate, collect, analyze, implement and follow effectively promote strategy-as-practice.

The study did not demonstrate moderation of dynamism and hostility in the relationships between SIS and BS, and the latter and CP. The strong economy contraction in 2015 and 2016, with a GDP of $-3.8 \%$ and $-3.6 \%$ respectively (IBGE, 2016, 2017), may have influenced the validation of the hypotheses, since the economic crisis imposes a restriction of resources for product/service launches, influencing the dynamism of the environment and the competition of the same resources imposed. However, similar results of non-moderation support for the dimensions of environmental uncertainty were found in studies conducted in stable economies (Newkirk \& Lederer, 2009, 2006).

The post-analysis study investigated the possibility of heterogeneity not observed by the FIMIX-PLS method (Hair et al., 2018), and identified two group segments that demonstrated that the aggregated analysis of the data level was consistent with the results found in the structural model for the observable variables of environmental control and uncertainty, with no statistically significant differences for the two FIMIX-PLS segments groups. 
However, the fsQCA analysis demonstrated the possibility of non-linear causality for the BS in solution 1 and 2 of FIMIX-PLS for the firm's size variable and the environmental uncertainty of heterogeneity. Moreover, it contributed to the understanding of how the intensive use of SIS in large enterprises can be equally effective in achieving a state of effect in BS, and confirmed PLS-PM of heterogeneity influence in BS.

Following, the post hoc analysis study allowed to identify the effect of the strategic alignment of SIS on CP, and in both methods of moderation and profile deviation presented a strong path effect, with statistical significance and high explanatory power in CP. The result contributes with studies that emphasize that process are not executed without the presence of IS/IT (Kohli \& Grover, 2008) and confirmed that SIS incorporated the strategic planning process, and can be considered inseparable for the success of the strategy-as-practice, positioning as IS strategizing, in the context of economic turbulence and environmental uncertainty.

This study contributed to Strategy-as-Practice researchers recognize the significance of material technology in strategy work and there are many potential avenues for mutual exchange and collaboration between IS field and Practice Theory.

It is possible to emphasize that the way of collecting data limited the generalization of the results obtained, since the sample was not probabilistic. The cross-sectional method imposed another limitation in the study to evaluate the relationship between the constructs.

As a future study, it is suggested to pursue analyses of the moderation of the ideal use of SIS strategic alignment in CP weighted by strategy types, such as leadership in cost, differentiation and focus (Porter, 1986), strategic orientation defense, analysis, proactivity and reaction of customer intimacy (Miles, Snow, Meyer, \& Coleman, 1978), operational excellence and product leadership (Mintzberg et al., 2009). Longitudinal research on the antecedents and consequences of SIS may generate new results from SIS value creation for strategy-as-practice, as well as its impact on innovation, competitive advantage and organizational performance over time.

\section{References}

Albertin, L. A., \& Albertin, R. M. de M. (2012). Dimensões do uso de tecnologia da informação: um instrumento de diagnóstico e análise. Revista de Administração Pública, 46(1), 125-151. https://doi.org/10.1590/S0034-76122012000100007

Anwar, J., \& Hasnu, S. (2016). Business strategy and firm performance: a multi-industry analysis. Journal of Strategy and Management, 9(3), 361-382. https://doi.org/10.1108/JSMA-09-2015-0071

Arvidsson, V., Holmström, J., \& Lyytinen, K. (2014). Information systems use as strategy practice: A multi-dimensional view of strategic information system implementation and use. Journal of Strategic Information Systems, 23(1), 45-61. https://doi.org/10.1016/j.jsis.2014.01.004

Atkinson, A. A., Kaplan, R. S., Matsumura, E. M., \& Young, S. M. (2011). Management Accounting: Information for Decision-making and Strategy Execution (6th ed.). Upper Saddle River: Prentice Hall.

Babafemi, I. D. (2015). Corporate Strategy, Planning and Performance Evaluation: A Survey of Literature. Journal of Management Policies and Practices, 3(1), 43-49. https://doi.org/10.15640/jmpp.v3n1a6

Becker, J., Rai, A., Ringle, C. M., \& Volckner, F. (2013). Discovering unobserved heterogeneity in structural equation models to avert validity threats. MIS Quarterly, 37(3), 665-694. https://doi.org/10.25300/MISQ/2013/37.3.01

Bento, A., Bento, R., \& White, L. (2013). Validating cause-and-effect relationships in the balanced scorecard. Academy of Accounting and Financial Studies Journal, 45-55.

Bromiley, P., \& Rau, D. (2014). Research prospectives towards a practice-based view of strategy. Strategic Management Journal, 35(1), 1249-1256. https://doi.org/10.1002/smj.2238

Carlson, K. D., \& Wu, J. (2012). The illusion of statistical control: control variable practice in management research. Organizational Research Methods, 15(3), 413-435. https://doi.org/10.1177/1094428111428817

Chan, Y. E., Denford, J. S., \& Jin, J. Y. (2016). Competing Through Knowledge and Information Systems Strategies: A Study of Small and Medium-Sized Firms. Journal of Information \& Knowledge Management. https://doi.org/10.1142/S0219649216500271

Chan, Y. E., Sabherwal, R., \& Thatcher, J. B. (2006). Antecedents and outcomes of strategic IS alignment: an empirical investigation. IEEE Transactions on Engineering Management, 53(1), 27-47. https://doi.org/10.1109/TEM.2005.861804

Chen, D. Q., Mocker, M., Preston, D. S., \& Teubner, A. (2010). Information Systems Strategy: Reconceptualization, Measurement, and Implications. MIS Quarterly, 34(2), 233-259. https://doi.org/10.2307/20721426 
Chen, Y., Wang, Y., Nevo, S., Jin, J., Wang, L., \& Chow, W. S. (2014). IT capability and organizational performance: the roles of business process agility and environmental factors. European Journal of Information Systems, 23(3), 326-342. https://doi.org/10.1057/ejis.2013.4

Chin, W. W., Thatcher, J. B., Wright, R. T., \& Steel, D. (2013). Controlling for common method variance in PLS analysis: the measured latent marker variable approach. In L. Abdi, H., Chin, W.W., Vinzi, V.E., Russolillo, G. and Trinchera (Ed.), New Perspectives in Partial Least Squares and Related Methods (pp. 231-239). New York: Springer. https://doi.org/10.1007/978-1-4614-8283-3_16

Dameron, S., Lê, J. K., \& Lebaron, C. (2015). Materializing Strategy and Strategizing Materials: Why Matter Matters. British Journal of Management, 26(S1), S1-S12. https://doi.org/10.1111/1467-8551.12084

Davenport, T. H., Harris, J. G., \& Morison, R. (2010). Analytics at Work: Smarter Decisions, Better Results. Harvard Business School Press Books. Retrieved from http://www.amazon.com/dp/1422177696\%5Cnhttp://books.google.com/books?id=2otJuvfvflgC\&pgis=1

Faul, F., Erdfelder, E., Lang, A. G., \& Buchner, A. (2007). G*Power 3: A flexible statistical power analysis program for the social, behavioral, and biomedical sciences. Behavior Research Methods, 39(2), 175-191. https://doi.org/10.3758/BF03193146

Fiss, P. C. (2011). Building better causal theories: A fuzzy set approach to typologies in organization research. Academy of Management Journal, 54(2), 393-420. https://doi.org/10.5465/amj.2011.60263120

Frambach, R. T., Fiss, P. C., \& Ingenbleek, P. T. M. (2016). How important is customer orientation for firm performance? A fuzzy set analysis of orientations, strategies, and environments. Journal of Business Research, 69(4), 1428-1436. https://doi.org/10.1016/j.jbusres.2015.10.120

George, G., Haas, M. R., \& Pentland, A. (2014). From the editors: Big data and management. Academy of Management Journal, 57(2), 321-326. https://doi.org/10.5465/amj.2014.4002

Grant, R. M. (2003). Strategic planning in a turbulent environment: Evidence from the oil majors. Strategic Management Journal, 24(6), 491-517. https://doi.org/10.1002/smj.314

Hair, J. F., Hult, G., Ringle, C., \& Sarstedt, M. (2016). A Primer on Partial Least Squares Structural Equation Modeling (PLS-SEM). Sage ( $2^{\circ}$ Ed.). Thousand Oaks.

Hair, J. F., Sarstedt, M., Matthews, L. M., \& Ringle, C. M. (2016). Identifying and treating unobserved heterogeneity with FIMIX-PLS: part I - method. European Business Review, 28(1), 63-76. https://doi.org/10.1108/EBR-09-2015-0094

Hair, J. F., Sarstedt, M., Ringle, C. M., \& Gudergan, S. P. (2018). Advanced Issues in Partial Least Squares Structural Equation Modeling. Thousand Oaks.

Heyden, M. L. M., Fourn, S. P. L., Koene, B. A. ., Werkman, R., \& Ansari, S. S. (2017). Rethinking “Top-Down” and "Bottom-Up" Roles of Top and Middle Managers in Organizational Change: Implications for Employee Support. Journal of Management Studies. https://doi.org/10.1111/joms.12258

Hill, C., Jones, G., \& Schilling, M. (2014). Strategic Management: Theory: An Integrated Approach. Boston, Massachusetts, USA: Cengage Learning.

IBGE. (2016). Contas Nacionais Trimestrais. Retrieved February 23, 2017, from $\mathrm{ftp} / / / \mathrm{ftp}$. ibge.gov.br/Contas_Nacionais/Contas_Nacionais_Trimestrais/Comentarios

IBGE. (2017). Contas Nacionais Trimestrais. Retrieved from ftp://ftp.ibge.gov.br/Contas_Nacionais/Contas_Nacionais_Trimestrais/Comentarios

Jarzabkowski, P., \& Kaplan, S. (2015). Strategy tools-in-use: a framework for understanding "technologies of rationality" in practice. Strategic Management Journal, 36. https://doi.org/10.1002/smj.2270

Johnson, A. M., \& Lederer, A. L. (2013). IS Strategy and IS Contribution: CEO and CIO Perspectives. Information Systems Management, 30(4), 306-318. https://doi.org/10.1080/10580530.2013.832962

Kaplan, R. S., \& Norton, D. P. (1992). The Balanced Scorecard: Measures that Drive Performance. Harvard Business Review, (January-February), 71-79.

Kaplan, R. S., \& Norton, D. P. (2008). The Execution Premium: Linking Strategy to Operations for Competitive Advantage. Boston: Harvard Business School Press.

Karpovsky, A., \& Galliers, R. D. (2015). Aligning in practice: From current cases to a new agenda. Journal of Information Technology, 30(2), 136-160. https://doi.org/10.1057/jit.2014.34

Kearns, G. S., \& Sabherwal, R. (2006). Strategic Alignment Between Business and Information Technology: A Knowledge-Based View of Behaviors, Outcome, and Consequences. Journal of Management Information Systems, 23(3), 129-162. https://doi.org/10.2753/MIS0742-1222230306 
Kim, G., Shin, B., Kim, K. K., \& Lee, H. G. (2011). IT Capabilities, Process-Oriented Dynamic Capabilities, and Firm Financial Performance. Journal of Association for Information Systems, 12(7), 487-517. https://doi.org/10.17705/1jais.00270

Kohli, R., \& Grover, V. (2008). Business Value of IT: An Essay on Expanding Research Directions to Keep up with the Times. Journal of the Association for Information Systems, 9(1), 23-39. https://doi.org/10.17705/1jais.00147

Leidner, D. E., Lo, J., \& Preston, D. S. (2011). An empirical investigation of the relationship of IS strategy with firm performance. Journal of Strategic Information Systems, 20(4), 419-437. https://doi.org/10.1016/j.jsis.2011.09.001

Lipitakis, A., \& Phillips, P. (2015). On e-business strategy planning and performance: a comparative study of the UK and Greece. Technology Analysis \& Strategic Management, 28(3), 1-24. https://doi.org/10.1080/09537325.2015.1094568

Lumpkin, G. T., \& Dess, G. G. (2001). Linking two dimensions of entrepreneurial orientation to firm performance: The moderating role of environment and industry life cycle. Journal of Business Venturing, 16(5), 429-451. https://doi.org/10.1016/S0883-9026(00)00048-3

Mao, H., Liu, S., \& Zhang, J. (2014). How the effects of IT and knowledge capability on organizational agility are contingent on environmental uncertainty and information intensity. Information Development, 31(4), 1-25. https://doi.org/10.1177/0266666913518059

Marabelli, M., \& Galliers, R. D. (2017). A reflection on information systems strategizing: the role of power and everyday practices. Information Systems Journal, 27(3), 347-366. https://doi.org/10.1111/isj.12110

Matthews, L. M., Sarstedt, M., Hair, J. F., \& Ringle, C. M. (2016). Identifying and treating unobserved heterogeneity with FIMIX-PLS Part II - A case study. https://doi.org/10.1108/EBR-09-2015-0095

Meirelles, F. S. (2018). Administração de recursos de informática: tecnologia de informação nas empresas panorama e indicadores (29a. edição). Sao Paulo: Fundação Getulio Vargas, Escola de Administração de Empresas de São Paulo, Centro de Tecnologia de Informação Aplicada. FGV-EAESP-CIA.

Melville, N., Kraemer, K., \& Gurbaxani, V. (2004). Review: Information Technology and Organizational Performance: An Integrative Model of IT Business Value. MIS Quarterly, 28(2), 283-322. https://doi.org/10.2307/25148636

Merali, Y., Papadopoulos, T., \& Nadkarni, T. (2012). Systems Information systems strategy : Past, present, future? Journal of Strategic Information Systems, 21(2), 125-153. https://doi.org/10.1016/j.jsis.2012.04.002

Mikalef, P., \& Pateli, A. (2017). Information technology-enabled dynamic capabilities and their indirect effect on competitive performance: Findings from PLS-SEM and fsQCA. Journal of Business Research, 70, 1-16. https://doi.org/10.1016/j.jbusres.2016.09.004

Miles, R. E., Snow, C. C., Meyer, A. D., \& Coleman, H. J. (1978). Organizational strategy Structure and Process.pdf. Academy of Management Review, 3(1), 546-562. https://doi.org/10.5465/amr.1978.4305755

Miller, D., \& Friesen, P. H. (1983). Strategy-making and enviroment: the third link. Strategic Management Journal, 4, 221-235. https://doi.org/10.1002/smj.4250040304

Mintzberg, H., Ahlstrand, B. W., \& Lampel, J. (2009). Strategy safari: The complete guide through the wilds of strategic management (2nd ed.). Harlow:UK: Financial Times Prentice Hall.

Mithas, S., Ramasubbu, N., \& Sambamurthy, V. (2011). How Information Management Capability Influences Firm Performance. MIS Quarterly, 35(1), 237-256. https://doi.org/10.2307/23043496

Mostaghel, R., Oghazi, P., Beheshi, H., \& Hultman, M. (2015). Strategic use of enterprise systems among service firms: Antecedents and consequences. Journal of Business Research, 1544-1549. https://doi.org/10.1016/j.jbusres.2015.01.049

Newkirk, H. E., \& Lederer, A. . (2009). The impact of environmental dynamism on strategic information systems technical and personnel resources planning. ... Technology and Management, 9(2), 203-223. Retrieved from http://www.inderscienceonline.com/doi/abs/10.1504/IJITM.2010.030461

Newkirk, H. E., \& Lederer, A. L. (2006). The effectiveness of strategic information systems planning under environmental uncertainty. Information \& Management, 43(4), 481-501. https://doi.org/10.1016/j.im.2005.12.001

Park, S., Lee, H., \& Chae, S. W. (2017a). Rethinking balanced scorecard ( BSC ) measures : formative versus reflective measurement models. https://doi.org/10.1108/IJPPM-08-2015-0109

Park, S., Lee, H., \& Chae, S. W. (2017b). Rethinking balanced scorecard (BSC) measures: formative versus reflective measurement models. International Journal of Productivity and Performance Management, 66(1), 
92-110. https://doi.org/10.1108/IJPPM-08-2015-0109

Pavlou, P. A., \& El Sawy, O. A. (2010). The "third hand": IT-enabled competitive advantage in turbulence through improvisational capabilities. Information Systems Research, 21(3), 443-471. https://doi.org/10.1287/isre.1100.0280

Peppard, J., Galliers, R. D., \& Thorogood, A. (2014). Information systems strategy as practice: Micro strategy and strategizing for IS. Journal of Strategic Information Systems, 23(1), 1-10. https://doi.org/10.1016/j.jsis.2014.01.002

Porter, M. E. (1986). Estratégia Competitiva: Técnicas para Análise de indústrias e da Concorrência (7th ed.). Rio de Janeiro: Editora Campus.

Ragin, C. C. (2008). Redesigning social inquiry: Fuzzy sets and beyond. Chicago: University of Chicago Press. https://doi.org/10.7208/chicago/9780226702797.001.0001

Ray, G., Wu, D., \& Konana, P. (2009). Competitive environment and the relationship between IT and vertical integration. Information Systems Research, 20(4), 585-603. https://doi.org/10.1287/isre.1080.0202

Ringle, C. M., Bido, D. S., \& Da Silva, D. (2014). Structural equation modeling with the SmartPLS. Brazilian Journal of Marketing, 13(2), 53-76. https://doi.org/10.5585/remark.v13i2.2717

Rouhani, S., Ashrafi, A., Ravasan, A. Z., \& Afshari, S. (2016). The impact model of business intelligence on decision support and organizational benefits. Journal of Enterprise Information Management, 29(1), 19-50. https://doi.org/10.1108/JEIM-12-2014-0126

Sabherwal, R., \& Chan, Y. E. (2001). Alignment between Business and IS Strategies: A Study of Prospectors, Analyzers, and Defenders. Information Systems Research. https://doi.org/10.1287/isre.12.1.11.9714

Sarstedt, M., Becker, J., Ringle, C. M., \& Schwaiger, M. (2011). Uncovering and Treating Unobserved Heterogeneity with FIMIX-PLS : Which Model Selection Criterion Provides an Appropriate Number of Segments? Schmalenbach Business Review, 63(January), 34-62. https://doi.org/10.1007/BF03396886

Schilke, O. (2014). On the Contingent Value of Dynamic Capabilities for Competitive Advantage: the Nonlinear Moderating Effect of Environmental Dynamism. Academy of Management Journal, 51(2), 179-203. https://doi.org/10.1002/smj.02099

Segars, A. H., \& Grover, V. (1998). Strategic Information Systems Planning Success: An Investigation of the Construct and Its Measurement. MIS Quarterly, 22(2), 139-163. https://doi.org/10.2307/249393

Segars, A. H., \& Grover, V. (1999). Profiles of Strategic Information Systems Planning. Information Systems Research, 10(3), 199-232. https://doi.org/10.1287/isre.10.3.199

Segars, A. H., Grover, V., \& Teng, J. T. C. (1998). Strategic information systems planning: Planning system dimensons, internal coalignment, and implications for planning effectiveness. Decision Sciences, 29(2), 303-345. https://doi.org/10.1111/j.1540-5915.1998.tb01579.x

Sen, D., Bingol, S., \& Vayway, O. (2017). Strategic Enterprise Management for innovative companies: the last decade of the balanced scorecard. International Journal of Asian Social Science, 7(1), 97-109. https://doi.org/10.18488/journal.1/2017.7.1/1.1.97.109

Shollo, A., \& Galliers, R. D. (2016). Towards an understanding of the role of business intelligence systems in organisational knowing. Information Systems Journal, 26(4), 339-367. https://doi.org/10.1111/isj.12071

Singh, S. K., Watson, H. J., \& Watson, R. T. (2002). EIS support for the strategic management process. Decision Support Systems, 33(1), 71-85. https://doi.org/10.1016/S0167-9236(01)00129-4

Skokan, K., Pawliczek, A., \& Piszczur, R. (2013). Strategic Planning and Business Performance of Micro, Small and Medium-Sized Enterprises. Journal of Competitiveness, 5(4), 57-72. https://doi.org/10.7441/joc.2013.04.04

Song, M., Zhao, Y., Arend, R. J., \& Im, S. (2015). Strategic planning as a complex and enabling managerial tool. Strategic Management Journal.

Tallon, P. P. (2007). A Process-Oriented Perspective on the Alignment of Information Technology and Business Strategy. Journal of Management Information Systems, 24(3), 227-268. https://doi.org/10.2753/MIS0742-1222240308

Teo, T. S. H., \& King, W. R. (1997). Integration between business planning and information systems planning: an evolutionary-contingency perspective. Journal of Management Information Systems. https://doi.org/10.1111/j.1540-5915.1997.tb01312.x

Tho, N. D., \& Trang, N. T. M. (2014). Can knowledge be transferred from business schools to business organizations through in-service training students? SEM and fsQCA fi ndings. Journal of Business Research. https://doi.org/10.1016/j.jbusres.2014.12.003 
Whittington, R. (2014). Journal of Strategic Information Systems Information Systems Strategy and Strategy-as-Practice: A joint agenda q. Journal of Strategic Information Systems, 23(1), 87-91. https://doi.org/10.1016/j.jsis.2014.01.003

Whittington, R., Yakis-Douglas, B., Ahn, K., \& Cailluet, L. (2017). Strategic Planners in More Turbulent Times: The Changing Job Characteristics of Strategy Professionals, 1960-2003. Long Range Planning, 50(1), 108-119. https://doi.org/10.1016/j.lrp.2015.12.021

Wilden, R., \& Gudergan, S. P. (2015). The impact of dynamic capabilities on operational marketing and technological capabilities: investigating the role of environmental turbulence. Journal of the Academy of Marketing Science, 43(2), 181-199. https://doi.org/10.1007/s11747-014-0380-y

Wolf, C., \& Floyd, S. W. (2017). Strategic Planning Research: Toward a Theory-Driven Agenda. Journal of Management, 43(6), 1754-1788. Retrieved from http://journals.sagepub.com/doi/10.1177/0149206313478185

Woodside, A. G., Ko, E., \& Huan, T. C. (2012). The new logic in building isomorphic theory of management decision realities. Management Decision, 50(5), 765-777. https://doi.org/10.1108/00251741211227429

Xue, L., Ray, G., \& Sambamurthy, V. (2012). Efficiency or Innovation: How Do Industry Environments Moderate the Effects of Firms'It Asset Portfolios? Mis Quarterly (Vol. 36).

Yayla, A. A., \& Hu, Q. (2012). The impact of IT-business strategic alignment on firm performance in a developing country setting: exploring moderating roles of environmental uncertainty and strategic orientation. European Journal of Information Systems, 21(4), 373-387. https://doi.org/10.1057/ejis.2011.52

Yoshikuni, A. C., \& Albertin, A. L. (2014). Model Analysis of the Relationship Between Strategic Organization Knowledge and the Use of Information Systems in Firm Performance in Brazil. Chinese Business Review, 13(5), 301-319.

Yoshikuni, A. C., \& Albertin, A. L. (2018a). Strategic Information Systems Enabling Strategy-as-practice Under Uncertain Environments. RAC - Revista de Administracao Contemporanea, 22(4), 552-576. https://doi.org/10.159Q/1982-7849rac2018170253

Yoshikuni, A. C., \& Albertin, A. L. (2018b). The Effects of Strategic Is on Firm Performance: An Empirical Study of the Three-Way Interaction Investigation of Turbulent Scenario. Journal of Public Administration and Governance, 8(4), 20. https://doi.org/10.5296/jpag.v8i4.13767

Yoshikuni, A. C., \& Albertin, L. A. (2017). IT-Enabled Dynamic Capability on Performance : an Empirical Study of. $R A E, 57$ (maio-jun), 215-231. https://doi.org/10.1590

\section{Copyrights}

Copyright for this article is retained by the author(s), with first publication rights granted to the journal.

This is an open-access article distributed under the terms and conditions of the Creative Commons Attribution license (http://creativecommons.org/licenses/by/4.0/). 